\title{
Balancing state and volunteer investment in biodiversity monitoring for the implementation of CBD indicators: A French example
}

\author{
Harold Levrel ${ }^{a,{ }^{*}}$, Benoît Fontaine ${ }^{b}$, Pierre-Yves Henry ${ }^{c}$, Frédéric Jiguet ${ }^{b}$, Romain Julliard ${ }^{b}$, Christian \\ Kerbiriou $^{\mathrm{b}}$ and Denis Couvet ${ }^{\mathrm{b}}$
}

\footnotetext{
a IFREMER, UMR AMURE, Marine Economics Department, ZI Pointe du Diable, BP70, 29280, Plouzané, France

${ }^{\mathrm{b}}$ Muséum National d'Histoire Naturelle, UMR 7204, 55 rue Buffon, 75005 Paris, France

${ }^{c}$ Département Ecologie et Gestion de la Biodiversité, UMR 7179, Muséum National d'Histoire Naturelle, 1 avenue du Petit Château, 91800 Brunoy, France
}

\author{
*: Corresponding author : Harold Levrel, Tel.: + 33298290085 27; fax: + 332982247 76, email address : \\ Harold.Levrel@ifremer.fr
}

\begin{abstract}
:
According to the Convention on Biological Diversity (CBD), states have to provide indicators in order to assess the performance of their initiatives for halting the loss of biodiversity. Sixteen headline indicators have been identified for monitoring the CBD targets. Of these indicators only one, "Trends in the abundance and distribution of selected species," is a direct headline indicator of "non-exploited" biodiversity. In France, the implementation of this indicator is completely dependent on data collected by volunteers. Since this investment of volunteer time is equivalent to savings in administrative costs, we attempt in this paper to assign it a monetary value. This enables us to estimate how much the French administration saves thanks to volunteer efforts and how much public funding would have to be invested if volunteers were no longer willing to participate in these biodiversity monitoring schemes. We estimate this amount to be between 678,523 and 4,415,251 euros per year, depending on the scenario selected.
\end{abstract}

Keywords: Biodiversity monitoring; CBD indicators; Citizen science; Replacement cost 


\section{Introduction: biodiversity indicators and volunteers in monitoring schemes}

The Convention on Biological Diversity (CBD) has identified goals for the halting of biodiversity loss by 2010 (CBD, 1992). To ensure that this commitment is followed through, the efforts undertaken by each country need to be tracked and measured (Dobson, 2005). For this purpose the first CBD indicators were established in February 2004, at the seventh Conference of the Parties to the Convention which took place in Kuala Lumpur (http://www.biodiv.org). Every EU member state has to fulfil the EU commitment to document headline indicators of biodiversity.

In Europe the implementation of the CBD has been outlined by the SEBI (Streamlining European 2010 Biodiversity Indicators) initiative "Halting the loss of biodiversity by 2010: proposal for a first set of indicators to monitor progress in Europe" (European Environment Agency, 2007, 2009; Green et al., 2005). The goal of this group of experts was to identify which of the proposed indicators could be implemented in the short term, under what conditions (Balmford et al. 2005; Levrel, 2007). The first headline indicators in their list, out of a total of 16 (Table 1), rely entirely on the availability of monitoring data for documenting the abundance and distribution of selected species of birds and butterflies.

This headline indicator is especially important for the CBD targets. When we review the CBD indicators in detail, we can see that only three of them can be considered "direct" core biodiversity indicators - "abundance and diversity of groups of species" (Balmford et al., 2005), the "Red List Index" (RLI) (Butchart et al., 2005), and the "Marine Trophic Index" (MTI) (Pauly and Watson, 2005). Others represent pressures on biodiversity or social responses to biodiversity loss (Balmford et al., 2005; Levrel et al., 2009). The RLI provides only qualitative information on the conservation status of species and does not detect short-term changes (Balmford et al., 2003), and the MTI is criticized because it is based only on commercial fish catches, not on a random scientific sampling (e.g., de Mutsert et al., 2008).

The fact that the headline indicator relies on the work of volunteers is not surprising. Data sets on biodiversity are usually developed by volunteer naturalists who collect information in their spare time (Schmeller et al., 2009; Bell et al., 2008; Julliard et al., 2004; Thomas, 2005; Cooper et al., 2007; Gregory et al., 2005; van Swaay et al., 2008). In France, for example, only $28.3 \%$ of biodiversity monitoring schemes $(n=93)$ are run by professional paid staff (Schmeller et al., 2009).

The substantial dependence of existing biodiversity monitoring schemes on local volunteers' availability is potentially a critical weakness of biodiversity monitoring strategies around the world. For instance, it means that attractive taxonomic groups receive by far the greatest attention, and that virtually no large-scale monitoring is in place in non-OECD countries (Balmford et al., 2003, 2005; Henry et al., 2008; Fontaine et al., 2007). On the other hand, the participation of local stakeholders in the development of monitoring schemes is a good way to improve the public's knowledge of biodiversity (Cooper et al., 2007), to launch collective learning-by-doing processes (Levrel and Bouamrane, 2008; Stringer et al., 2006), to support public debates, and of course to effect savings in the public costs of biodiversity monitoring (Schmeller et al., 2009; Couvet et al., 2008).

The purpose of the present paper is to address this last point - savings in public costs - and to make explicit the economic contribution of volunteer labor to the production of biodiversity indicators, using a French example. It is intended to demonstrate to policymakers how much is saved by the French government department responsible for providing biodiversity indicators for monitoring progress towards the 2010 CBD targets, thanks to the commitment of volunteers in France. 


\section{Methods}

According to the economics literature, there are several methods for valuing the "shadow wages" of the volunteer workforce (Brown, 1999; Steinberg, 1990). These fall into two types (Prouteau et Wolff, 2004), the output-related and the input-related methods.

The output-related method is based on volunteers' contribution to the revenue (VCR) of an organization. Under this method, the value of volunteer work is equal to the value of the additional output produced by the work in question (Foster et al., 2001). The valuation process requires collecting information about five parameters: input quantity (volunteer effort), output quantity (production), output prices, revenues, and the links between them. Theoretically, the VCR is the soundest method for producing a volunteer effort valuation, because "it varies with the degree of substitution between volunteers and paid labor" (Bowman, 2009, pp.496-497). However, a crucial limitation of this approach is the lack of the data required to perform the valuation, especially the market value of outputs in the non-profit sector. It is even more difficult to identify which part of this potential output is derived specifically from volunteer work. Thus, even if this method is the most robust, it is not relevant for our assessment.

The input-related method takes into account the market value of the input, that is, the cost of the labor force. Using this second approach, one or other of two specific costs can be calculated, the workers' opportunity cost or the replacement cost for the organization.

The workers' opportunity cost approach assumes that one hour spent in a volunteer activity can be considered equal to one hour spent in a paid activity, in other words that volunteer work and paid activity have the same value for the worker. This assumption is debatable for two main reasons (Prouteau and Wolff, 2004). The first is related to the underlying assumption that the labor market is entirely flexible and that it is feasible to switch from volunteer to paid work without any constraints. This is not the case in the real world. The second problem is related to the comparative value of one unit of time of paid work vis-à-vis one unit of time of volunteer work. The assumption that these values can be considered substitutable is not in fact realistic, because the individual utility functions depending on paid and volunteer activities are not comparable. The utility derived from paid work depends on the salary level and on the time spent doing the work (which is theoretically a source of disutility). For volunteer work, utility and disutility depend on several factors that are difficult to disentangle (output, time, personal beliefs, gratitude of others, etc.). People are usually unable to compare the time they spend in volunteer and paid work, although this is a necessary condition for applying the opportunity cost method.

The primary method used for the monetary valuation of volunteer activity is therefore the replacement cost method (Foster et al, 2001; United Nations, 2003). With this method, the valuation is based on what an organization would have to pay employees to do the work that they usually benefit from at no cost as a result of volunteer activity.

The main weakness of the replacement cost method is that it assumes that paid labor and volunteer labor are one-to-one equivalents in the production process (Bowman, 2009). If volunteer and paid labor were complementary in the production process, the replacement cost method would be completely invalid for assessing the value of the volunteer effort, whereas the evaluation of the VCR would still be usable (Bowman, 2009). Several arguments have in fact been advanced to suggest that volunteer and paid labor could be complementary rather than substitutable. These arguments are of two types: the first relates to the risk of bias, the second to differences in productivity.

The risk of bias in biodiversity monitoring.

Volunteers' and paid workers' motivations for participating in biodiversity monitoring may differ. Volunteers may get involved in monitoring activities because they want to contribute to improved protection of biodiversity, while paid staff may be "neutral" experts. Volunteers might thus be suspected of biasing their monitoring data. 
This bias is not confirmed by the literature. The quality of the data on biodiversity and the degree of bias are not correlated with data collection by inexperienced observers but with other parameters: (1) the availability of survey design, techniques, and guidelines that can be used by volunteers without lengthy or specialist training (Darwall and Dulvy, 1996; Newman et al., 2003; Foster-Smith and Evans, 2003); (2) the need to validate protocols and data sets using standard quantitative methods (Henry et al., 2008; Engel and Voshell, 2002); (3) the ability to coordinate and operate a network that includes different communities of practice (Levrel, 2006; Ohl et al., 2007). We detail how we have taken these elements into account in the Materials section.

\section{Productivity in data collection.}

Two criticisms of the level of productivity of volunteer work can be advanced: varying levels of skill and training (Handy and Srinivasan, 2004), and wide variation in the commitment of volunteers (Brown, 1999).

Collecting raw data, that is, quantifying the state (quantity, location) of species at a set of monitoring sites, usually requires basic naturalist knowledge. The monitor needs to master species identification, location on a map, counting, and rigorously following a monitoring protocol. It seems reasonable to assume that volunteers can perform these tasks as well as paid professionals This is congruent with the fact that in OECD countries volunteer specialists in species identification, taxonomy, and censusing now vastly outnumber professionals (Schmeller et al., 2009). We attempt to clarify the productivity issue through the description in the Materials section of the skill level required and the level of responsibility of the volunteers involved in the monitoring schemes.

An additional empirical indication that volunteer and paid professional monitoring can be substitutable is that European biodiversity monitoring schemes involve between $83 \%$ (average for Germany) and 0 \% (average for Poland) volunteer effort (Schmeller et al., 2009, p.313) to deliver the same type of information (biodiversity indicators).

We thus conclude that volunteers are not a source of bias in the monitoring of biodiversity and that they are not less productive than paid staff. Consequently, we believe that the replacement cost method can be used to assess the value of volunteer effort in relation to the development of biodiversity indicators.

\section{Materials}

As noted above, many states are completely dependent on nationwide monitoring of birds and butterflies to document the EU headline indicators of trends in the abundance and distribution of selected species. In France, the National Museum of Natural History is in charge of the implementation of indicators of common birds (STOC-EPS and STOCCAPTURE schemes) and butterflies (STERF and OPJ schemes) through the national VigieNature monitoring program (Table 2; http://www2.mnhn.fr/vigie-nature/). This program relies on the idea of the "citizen scientist," since those who collect data on biodiversity are all volunteers. It conforms to the three parameters listed above in the Methods section with reference to limiting the risk of bias in biodiversity monitoring schemes (Table 3).

In order to estimate the replacement costs in our case study, we began by calculating the amount of volunteer labor required to collect the total quantity of biodiversity data for the four Vigie-Nature schemes in 2008 (Table 4). We then added the amount of time required to convert data into the appropriate electronic format and that required for local coordination. Estimates of fieldwork hours have been provided by the national managers of each scheme, who are the ones best informed for this task: they have developed, tested, and implemented protocols with volunteers. Our estimate method did not take into account the use of personal and public equipment for monitoring species (such as rings, nets, binoculars, and cars), which is provided more or less equally by public organizations and volunteers. We show the detail of volunteer efforts for each monitoring system in Table 4. 
Next, we selected three average per-hour salary levels for the monitoring work and added French social security taxes (around $50 \%$ of gross salary) where relevant. These valuations were computed based on three sources (Table 5):

- Valuation A: Fees charged by an environmental consulting organization to supply ecological diagnostics and biodiversity monitoring: that is, how much the state would have to pay for biodiversity monitoring carried out by experts (based on the average of the costs for an expert study supplied by one public organization, one private firm, and one naturalist NGO).

- Valuation B: The salary level of staff in charge of environmental monitoring in a French public organization, that is, how much the state would have to pay employees working yearround on biodiversity monitoring (based on the average salary plus social security tax per hour, using the salary scale of a university, a public organization, and a public firm).

- Valuation C: The guaranteed French minimum wage, which might represent what naturalists would be willing to be paid for spending their spare time in biodiversity monitoring, given that most young naturalists consider that it is a plus to be paid anything at all for doing what they love to do and that funds are critically low for this activity (based on the official national guaranteed minimum wage plus social security tax).

In addition, three salary levels have been identified corresponding to the level of ability required for the different types of monitoring (Tables 5 and 6). The two criteria chosen to define the level of ability were "level of responsibility" (possession of a relevant qualification) and "skill level" (training received in order to be able to carry out the monitoring). These two criteria enable us to clarify the productivity issue raised in the Methods section. The higher the level of ability required for monitoring, the longer the time invested in it, as detailed in the number of person-days per site and visit (Table 7).

Three classes of employee were thus identified for each of the valuations: "no specific skills required," "long training or major responsibility required," "long training and major responsibility required," corresponding respectively to "low expertise," "medium expertise," and "high expertise."

Once the total of hours worked has been determined, we can calculate the total value of volunteer efforts in terms of time and monetary units for each monitoring system (Table 8).

\section{Results and discussion}

Our replacement valuation scenarios are summarized in Table 8. They produce an estimate of around 31 full-time positions, equivalent to between 4,415,251 euros (valuation A) and 678,523 euros (valuation C) saved in $2007-2008$ by the French public administration, thanks to French naturalists.

These assessments enable us to estimate what the public investment required to implement two of the most important CBD indicators would be if volunteers were no longer willing to participate in biodiversity monitoring schemes.

Because biodiversity monitoring efforts are mostly concentrated in a short period of time, fulltime year-round staffing does not reflect the real rhythm of monitoring work. It is clearly more efficient and feasible to mobilize a large number of specialists during a short period of time. This is why we can claim that the lower and medium valuations ( $B$ and $C$ ) underestimate the real replacement cost, and that the higher valuation $(A)$ is the most realistic, at least during the first years. In the other two cases, full-time public staffing would still require additional consultant work during the "high season" for monitoring.

An important point to stress is that all these monitoring systems have been developed and operated by national coordinators - researchers and engineers who depend on state investment. These researchers and engineers have also contributed to the development of the biodiversity indicators required for the CBD; it is thus important to balance the level of volunteer effort against that of state investment with respect to the coordination of these monitoring systems. In 2007 there were around 10 full-time paid staffers working in the four Vigie-Nature programs, for 16,000 hours per year altogether (source: French National Museum of Natural History). Of these, 1,200 hours were worked by PhD students, 400 by senior scientists, 2,000 by junior scientists, 4,800 by engineers, 5,200 by technicians, 1600 
by assistant professors, and 800 by secretarial staff, for total salary costs of around 302,000 euros annually. If we were to add volunteer efforts to that total, operating the Vigie-Nature programs would have required around 41 full-time positions, costing between 980,523 and $4,717,251$ euros.

The proportion of volunteers in these schemes is between $69 \%(678,523$ of 980,523 euros) and $93 \%(4,415,251$ of $4,717,251$ euros) in monetary terms and around $75 \%$ (31 of 41 positions) in full-time staffing equivalencies. If we compare this ratio with the overall ratio calculated for all biodiversity monitoring programs in France $(n=93)$, we find that the latter are fairly similar, with a ratio of $66.7 \%$ volunteers (Schmeller et al., 2009, Table 7).

Using the same sources of information, we also compared the level of volunteer effort in the Vigie-Nature programs, in terms of numbers of persons, sites monitored, and site visits, with that of French and European programs overall (Table 7). We note that the number of persondays and number of sites for the Vigie-Nature schemes seem to be substantially higher than those of French and European biodiversity schemes in general. This is chiefly due to the fact that the Vigie-Nature schemes operate on a nationwide scale, whereas the others listed are a mix of national and local initiatives. If we use a weighted index based on the number of person-days per site and visit (Table 7 ) and we take into account the different levels of ability required for each scheme (Table 6), we can see that the efforts required for the Vigie-Nature schemes are more or less equal to those of the others.

It is also possible to compare the Vigie-Nature schemes with other French schemes that use paid staff to implement national CBD indicators. Fishery and forestry monitoring schemes are good examples: they rely on paid workers to provide CBD indicators related to headline indicator number 12, "Area of forest, agricultural, fishery, and aquaculture ecosystems under sustainable management." The French Forest Inventory (Inventaire Forestier National) has developed a monitoring system based on 7000 sites, each requiring one and a half work days, that is, around 73,500 hours or 46 full-time staff (source: French Forest Inventory). The French fish monitoring program, managed by the French Research Institute for Exploitation of the Sea (Institut Français de Recherche pour l'Exploitation de la Mer) is split into one program on fish stock assessment and another on fishing activity. For the fish stock assessment which provides CBD indicators, 44,475 hours per year are invested in monitoring, equivalent to 28 full-time staff (source: French Research Institute for Exploitation of the Sea). Compared to other large-scale national biodiversity monitoring schemes that provide CBD indicators, the Vigie-Nature schemes thus appear to call for a standard amount of work.

In conclusion, we would like to open up the discussion of public investment in biodiversity monitoring programs. It is not usual for private individuals to take responsibility for developing monitoring systems that affect major political issues in a "modern" state. State-funded and paid monitoring schemes for managing information relevant to major political issues have been in place for a long time. This is true not only for traditional socio-economic questions such as unemployment and GNP growth but also for natural resources with a market value, as noted above with respect to the forest and fishery examples. Today, however, the conservation of biodiversity with no apparent market value has become a major political issue, just like climate change. This development means that the state now has to implement the CBD indicators. Providing an approximate valuation of the volunteer effort required to implement these indicators in France is a first step toward reminding French decision-makers and the national government that volunteers save them a lot of money. These volunteers would be justified in calling on the French government to invest an equivalent amount in this area.

How could such an investment be used to encourage volunteer participation in biodiversity monitoring?

One way to reinvest the money that the French state saves because of volunteer effort would be to give tax rebates to volunteers in monitoring programs, based on the time they spend annually on this activity. These tax rebates already exist in France for cash donations to NGOs. Contributing one's time to NGOs (local coordinators are often NGOs), to state-funded research programs, or simply to nature, ought also to be a source of savings for individuals, 
not only for the public administrations involved. It would also provide a strong economic incentive to participate in biodiversity monitoring.

Secondly, the state could invest in the operation and coordination of new biodiversity monitoring networks in France. Existing volunteer-based monitoring systems cover only a few taxonomic groups (Schmeller et al., 2009). The state should be proactive in biodiversity monitoring, funding studies to gather data on taxa which are not covered by volunteer science (in particular the poorly known invertebrates: Fontaine et al., 2007). Another important point is that the existing Vigie-Nature monitoring schemes document trends in the abundance and distribution of widespread and relatively common species. These trends are fundamental, in the sense that they characterize the core state of these taxonomic groups. However, the species most likely to become extinct in the short term are very localized ones with small populations, and these species are not well covered by current Vigie-Nature schemes. A complementary set of monitoring schemes could be set up to develop national networks for monitoring these rare species. Often, data have already been collected (cf. LIFE projects, local NGOs), but they may need to be integrated into national quantitative indicators (Henry et al., 2008), which offer more powerful ways of identifying trends than indicators based on the qualitative evaluation of conservation status (Butchart et al., 2005). Information on functional biodiversity, based on engineer species or on the functional traits of species, for instance, is also needed in order to develop new functional biodiversity indicators and eventually new ecosystem service indicators (De Groot et al., 2002; Quétier et al., 2007; Díaz et al., 2007).

Thirdly, the state could invest in countries which have no funds of their own for biodiversity monitoring. "Citizen science" principles are being applied mainly in OECD countries at this point, and are not really in place in most of the developing countries, where the amount of biodiversity and the lack of scientific knowledge are both extensive. Only local monitoring programs exist, often relying on short-term local community involvement (Danielsen et al., 2005). Public investment by the North ought therefore to support initiatives related to biodiversity monitoring in developing countries, especially training in "citizen science" activities (Danielsen et al., 2009). These monitoring systems will need to address information on the interaction between development and conservation issues, if they are to make sense in these poor areas (Levrel and Bouamrane, 2008). For the sake of efficiency, volunteer monitoring schemes might focus on the collection of basic data during daily activities (Rudd, 2004) such as fishing, hunting, or gathering, for example, especially with respect to invasive species. As noted by J.A. Thomas (2005, p.354), in a discussion of successful butterfly monitoring in the UK, "It will be possible to repeat these successes in many other nations, as has already been demonstrated in parts of Europe. To be successful, however, it is essential to have a well-funded institutional group to organize data gathering and to collate and analyse the results, as well as a determined leader to establish each scheme at the outset ...."

Lastly, the funding could simply be allocated to biodiversity conservation in general and used for any biodiversity conservation project, but especially for supporting small local environmental NGOs, which find it difficult to secure funding for their local monitoring programs.

It is clearly not easy to know which of these options might be the best way to improve biodiversity conservation. Other "compensation" options could be proposed that we have not listed here. A cost-benefit or cost-efficiency analysis for prioritizing them all would be difficult to carry out, since data are lacking and policy priorities in biodiversity monitoring are partly subjective. Serious discussion of both the scientific and political aspects will have to take place to identify the most efficient and informative monitoring systems with a view to investing in them. 


\section{Acknowledgments}

We would like to thank the local coordinators of Vigie-Nature; all the volunteers who participate in biodiversity monitoring in the Vigie-Nature program; Cécile Edelist and JeanLouis Gaignon for their valuable comments; and Luc Manil for information about the STERF scheme.

\section{References}

Balmford, A., Green, R.E., Jenkins, M., 2003. Measuring the changing state of nature. Trends in Ecology and Evolution 18(7), 326-330.

Balmford, A., Crane, P., Dobson, A., Green, R.E., Mace, G.M., 2005. The 2010 challenge: data availability, information needs and extraterrestrial insights. Philosophical Transactions of the Royal Society B. 360, 221-228.

Bas, Y., Devictor, V., Moussus, J.P., Jiguet, F., 2008. Accounting for weather and time-ofday parameters when analysing count data from monitoring programs. Biodiversity and Conservation 17, 3403-3416.

Bell, S., Marzano, M., Cent, J., Kobierska, H., Podjed, D., Vandzinskaite, D., Reinert, H., Armaitiene, A., Grodzińska-Jurczak, M., Muršič, R., 2008. What counts? Volunteers and their organisations in the recording and monitoring of biodiversity. Biodiversity and Conservation $17,3443-3454$.

Bowman, W., 2009. The economic value of volunteers to nonprofit organizations. Nonprofit Management \& Leadership 19(4),.491-506.

Brown, E., 1999. Assessing the value of volunteer activity. Non-Profit and Voluntary Sector Quarterly 28, 3-17.

Butchart, S.H.M., Stattersfield, A.J., Baillie, J., Bennun, L.A., Stuart, S.N., Akçakaya, H.R., Hilton-Taylor, C., Mace, G.M., 2005. Using Red List Indices to measure progress towards the 2010 target and beyond. Philosophical Transactions of the Royal Society B. 360, 255-268.

Convention on Biological Diversity, 1992. [Online] URL: http://www.biodiv.org/doc/legal/cbdun-en.pdf, 33 pp.

Cooper, C. B., Dickinson, J., Phillips, T., Bonney, R., 2007. Citizen science as a tool for conservation in residential ecosystems. Ecology and Society 12(2): 11. [Online] URL: http://www.ecologyandsociety.org/vol12/ iss2/art11/

Couvet, D., Jiguet, F., Julliard, R., Levrel, H., Teyssèdre, A., 2008. Enhancing citizen contributions to biodiversity science and public policy. Interdisciplinary Science Reviews 33(1), 95-103.

Danielsen, F., Burgess, N.D., Balmford, A., 2005. Monitoring matters: examining the potential of locally-based approaches. Biodiversity Conservation 14, 2507-2542.

Danielsen, F., Burgess, N.D., Balmford, A., Donald, P.F., Funder, M., Jones, J.P.G., Alviola, P., Balete, D.S., Blomley, T., Brashares, J., Child, B., Enghoff, M., Fjeldså, J., Holt, S., Hübertz, H., Jensen, A.E., Jensen, P.M., Massao, J., Mendoza, M.M., Ngaga, Y., Poulsen, M.K., Rueda, R., Sam, M., Skielboe, T., Stuart-Hill, G., Topp-Jørgensen, E., Yonten, D., 
2009. Local participation in natural resource monitoring: a characterization of approaches. Conservation Biology 23(1), 31-42.

Darwall, W.R.T., Dulvy, N.K., 1996. An evaluation of the suitability of non-specialist volunteer researchers for coral reef fish surveys. Mafia Island, Tanzania - a case study. Biological Conservation 78, 223-231.

De Groot, R.S., Wilson, M.A., Boumans, R.M.J., 2002. A typology for the classification, description and valuation of ecosystem functions, goods and services. Ecological Economics 41, 393-408.

De Mutsert, K., Cowan, J.H. Jr., Essington, T.E., Hilborn, R., 2008. Reanalyses of Gulf of Mexico fisheries data: landings can be misleading in assessments of fisheries and fisheries ecosystems. PNAS 105(7), 2740-2744.

Díaz, S., Lavorel, S., de Bello, F., Quétier, F., Grigulis, K., Robson, T.M., 2007. Incorporating plant functional diversity effects in ecosystem service assessments. PNAS 104(52), 2068420689.

Dobson, A., 2005. Monitoring global rates of biodiversity change: challenges that arise in meeting the Convention on Biological Diversity (CBD) 2010 goals. Philosophical Transactions of the Royal Society B. 360, 229-241.

Engel, S. R., Voshell, J. R. Jr., 2002. Volunteer biological monitoring: can it accurately assess the ecological condition of streams? American Entomologist 48, 164-177.

European Environment Agency, 2007. Halting the loss of biodiversity by 2010: proposal for a first set of indicators to monitor progress in Europe. EEA Report, Copenhagen.

European Environment Agency, 2009. Progress towards the European 2010 biodiversity targets. EEA Report, Copenhagen.

Fontaine, B., Bouchet, P., van Achterberg, K., Alonso-Zarazaga, M.A., Araujo, R., Asche, M., Aspöck, U., Audisio, P., Aukema, B., Bailly, N., Balsamo, M., Bank, R.A., Barnard, P., Belfiore, C., Bogdanowicz, W., Bongers, T., Boxshall, G., Burckhardt, D., Camicas, J.-L., Chylarecki, P., Crucitti, P., Deharveng, L., Dubois, A., Enghoff, H., Faubel, A., Fochetti, R., Gargominy, O., Gibson, D., Gibson, R., Gómez López, M.S., Goujet, D., Harvey, M.S., Heller, K.-G., van Helsdingen, P., Hoch, H., de Jong, H., de Jong, Y., Karsholt, O., Los, W., Lundqvist, L., Magowski, W., Manconi, R., Martens, J., Massard, J.A., Massard-Geimer, G., Mcinnes, S.J., Mendes, L.F., Mey, E., Michelsen, V., Minelli, A., Nieksen, C., Nieto Nafría, J.M., van Nieukerken, E.J., Noyes, J., Pape, T., Pohl, H., de Prins, W., Ramos, M., Ricci, C., Roselaar, C., Rota, E., Schmidt-Rhaesa, A., Segers, H., Zur Strassen, R., Szeptycki, A., Thibaud, J.-M., Thomas, A., Timm, T., van Tol, J., Vervoort, W., Willmann, R., 2007. The European Union's 2010 target: putting rare species in focus. Biological Conservation 139 (12), 167-185.

Foster, V., Mourato, S., Pearce, D., Özdemiroglu, E., 2001. The Price of Virtue: The Economic Value of the Charitable Sector. Edward Elgar, Cheltenham, UK.

Foster-Smith, J., Evans, S.M., 2003. The value of marine ecological data collected by volunteers. Biological Conservation 113(2), 199-213.

Green, R.E., Balmford, A., Crane, P.R., Mace, G.M., Reynolds, J.D., Turner, R.K., 2005. A framework for improved monitoring of biodiversity: responses to the World Summit on Sustainable Development. Conservation Biology 19, 56-65. 
Gregory, R.D., van Strien, A., Vorisek, P., Meyling, A.W.G., Noble, D.G., Foppen, R.P.B., Gibbons, D.W., 2005. Developing indicators for European birds. Philosophical Transactions of the Royal Society B. 360, 269-288.

Handy, F., Srinivasan, N., 2004. Valuing volunteers: an economic evaluation of the net benefits of hospital volunteers. Nonprofit and Voluntary Sector Quarterly 33(1), 28-54.

Henry, P.-Y., Lengyel, S., Nowicki, P., Julliard, R., Čelik, T., Gruber, B., Schmeller, D.S., Babij, V., Clobert, J., Henle, K., 2008. Integrating ongoing biodiversity monitoring: potential benefits and methods. Biodiversity and Conservation 17, 3357-3382.

Hochachka, W.M., Martin, K., Doyle, F., Krebs, C.J., 2000. Monitoring vertebrate populations using observational data. Canadian Journal of Zoology 78, 521-529.

Jiguet, F., 2009. Method-learning caused first-time observer effect in a newly-started breeding bird survey. Bird Study 56(2), 253-258.

Julliard, R., Jiguet, F., Couvet, D., 2004. Common birds facing global changes: what makes a species at risk? Global Change Biology 10(1), 148-154.

Levrel, H., 2006. Construire des indicateurs durables à partir d'un savoir issu de multiples pratiques : le cas de la biodiversité. Annales des Mines - Série Gérer \& Comprendre 85, 5162.

Levrel, H., 2007. Selecting indicators for the management of biodiversity. IFB Editions, Paris.

Levrel, H., Bouamrane, M., 2008. Instrumental learning and sustainability indicators: outputs from co-construction experiments in West African biosphere reserves. Ecology and Society 13(1): 28. [Online] URL: http://www.ecologyandsociety.org/vol13/iss1/art28/

Levrel, H., Kerbiriou, C., Couvet, D., Weber, J., 2009. OECD pressure-state-response indicators for managing biodiversity: a realistic perspective for a French biosphere reserve. Biodiversity and Conservation 18, 1719-1732.

Newman, C., Buesching, C.D., Macdonald, D.W., 2003. Validating mammal monitoring methods and assessing the performance of volunteers in wildlife conservation - "Sed quis custodet ipsos custodes". Biological Conservation 113, 189-197.

Ohl, C., Krauze, K., Grünbühel, C.M., 2007. Towards an understanding of long-term ecosystem dynamics by merging socio-economic and environmental research. Criteria for long-term socio-ecological research sites selection. Ecological Economics 63, 383-391.

Pauly, D., Watson, R., 2005. Background and interpretation of the 'Marine Trophic Index' as a measure of biodiversity. Philosophical Transactions of the Royal Society B. 360, 415-423.

Prouteau, P., Wolff, F-C., 2004. Le travail bénévole : un essai de quantification et de valorisation. Economie et Statistique 373, 33-56.

Quétier, F., Lavorel, S., Thuiller, W., Davies, I., 2007. Plant-trait-based modelling assessment of ecosystem service sensitivity to land-use change. Ecological Applications 17, 2377-2386.

Rudd, M.A., 2004. An institutional framework for designing and monitoring ecosystem-based fisheries management policy experiments. Ecological Economics 48(1), 109-124. 
Schmeller, D.S., Henry, P.-Y., Julliard, R., Clobert, J., Gruber, B., Dziock, F., Lengyel, S., Nowicki, P., Déri, E., Budrys, E., Kull, T., Tali, K., Bauch, B., Settele, J., van Swaay, C., Kobler, A., Babij, V., Papastergiadou, E., Henle, K., 2009. Advantages of volunteer-based biodiversity monitoring in Europe. Conservation Biology 23(2), 307-316.

Steinberg, R., 1990. Labor economics and the nonprofit sector: a literature review. Non-Profit and Voluntary Sector Quarterly 19, 151-169.

Stringer, L.C., Dougill, A.J., Fraser, E., Hubacek, K., Prell, C., Reed, M.S., 2006. Unpacking "participation" in the adaptive management of social-ecological systems: a critical review. Ecology and Society 11(2): 39. http://www.ecologyandsociety.org/vol11/iss2/art39/

Thomas, J.A., 2005. Monitoring change in the abundance and distribution of insects using butterflies and other indicator groups. Philosophical Transactions of the Royal Society B. 360, 339-357.

United Nations, 2003. Handbook on Non-Profit Institutions in the System of National Accounts. Studies in Methods, Series F., no. 91, Department of Economic and Social Affairs, Statistics Division, United Nations, New York.

van Swaay, C.A.M., Nowicki, P., Settele, J., Strien, A.J., 2008. Butterfly monitoring in Europe - methods, applications and perspectives. Biodiversity and Conservation 17, 3455-3469. 
Table 1: The SEBI biodiversity indicators

\begin{tabular}{|c|c|c|}
\hline Focal area & Headline indicators & $\begin{array}{l}\text { Indicators proposed by the SEBI for } \\
2010\end{array}$ \\
\hline \multirow{7}{*}{$\begin{array}{l}\text { Status and trends of the } \\
\text { components } \\
\text { biological diversity }\end{array}$} & $\begin{array}{l}\text { 1- Trends in the abundance and } \\
\text { distribution of selected species }\end{array}$ & \begin{tabular}{|l|} 
1-a) Common birds \\
1-b) Butterflies
\end{tabular} \\
\hline & $\begin{array}{l}\text { 2- Change in status of } \\
\text { threatened and/or protected } \\
\text { species }\end{array}$ & \begin{tabular}{|l|l|}
$\begin{array}{l}\text { 2-a) Red List Index for European } \\
\text { species }\end{array}$ \\
3-b) Species of European interest \\
\end{tabular} \\
\hline & \multirow{2}{*}{$\begin{array}{l}\text { 3- Trends in extent of selected } \\
\text { biomes, ecosystems, and } \\
\text { habitats }\end{array}$} & 3-a) Ecosystem coverage \\
\hline & & 3-b) Habitats of European interest \\
\hline & $\begin{array}{l}\text { 4- Trends in genetic diversity of } \\
\text { domesticated animals, cultivated } \\
\text { plants, and fish species of major } \\
\text { socio-economic importance }\end{array}$ & 4) Livestock genetic diversity \\
\hline & \multirow[t]{2}{*}{ 5- Coverage of protected areas } & $\begin{array}{l}\text { 5-a) Nationally designated protected } \\
\text { areas }\end{array}$ \\
\hline & & $\begin{array}{l}\text { 5-b) Sites designated under the EU } \\
\text { Habitats and Birds Directives }\end{array}$ \\
\hline \multirow[t]{3}{*}{ Threats to biodiversity } & 6- Nitrogen deposition & 6) Exceeding critical levels of nitrogen \\
\hline & $\begin{array}{l}\text { 7- Trends in invasive alien } \\
\text { species }\end{array}$ & 7) Invasive alien species in Europe \\
\hline & $\begin{array}{l}\text { 8- Impact of climate change } \\
\text { on biodiversity }\end{array}$ & $\begin{array}{l}\text { 8) Occurrence of temperature-sensitive } \\
\text { species }\end{array}$ \\
\hline \multirow{5}{*}{$\begin{array}{l}\text { Ecosystem integrity and } \\
\text { ecosystem goods and } \\
\text { services }\end{array}$} & 9- Marine Trophic Index & $\begin{array}{l}\text { 9) Marine Trophic Index of European } \\
\text { seas }\end{array}$ \\
\hline & \multirow{2}{*}{\begin{tabular}{|l|}
$10-\quad$ Connectivity/fragmentation \\
of ecosystems
\end{tabular}} & $\begin{array}{l}\text { 10-a) Fragmentation of natural and } \\
\text { semi-natural areas }\end{array}$ \\
\hline & & $\begin{array}{l}\text { 10-b) Status of and trends in river } \\
\text { fragmentation }\end{array}$ \\
\hline & \multirow[t]{2}{*}{$\begin{array}{l}\text { 11- Water quality in aquatic } \\
\text { ecosystems }\end{array}$} & $\begin{array}{l}\text { 11-a) Nutrients in transitional, coastal, } \\
\text { and marine waters }\end{array}$ \\
\hline & & 11-b) Freshwater quality \\
\hline \multirow[t]{7}{*}{ Sustainable use } & \multirow{6}{*}{$\begin{array}{l}\text { 12- Area of forest, agricultural, } \\
\text { fishery, and aquaculture } \\
\text { ecosystems under sustainable } \\
\text { management }\end{array}$} & $\begin{array}{l}\text { 12-a) Growing stock, increment, and } \\
\text { fellings (forest) }\end{array}$ \\
\hline & & 12-b) Deadwood (forest) \\
\hline & & $\begin{array}{ll}\begin{array}{l}\text { 12-c) Nitrogen balance (input/output) } \\
\text { (agriculture) }\end{array} \\
\end{array}$ \\
\hline & & $\begin{array}{l}\text { 12-d) Area under management using } \\
\text { practices potentially supporting } \\
\text { biodiversity (agriculture) }\end{array}$ \\
\hline & & $\begin{array}{l}\text { 12-e) European commercial fish stocks } \\
\text { (fisheries/aquaculture) }\end{array}$ \\
\hline & & $\begin{array}{l}\text { 12-f) Effluent water quality from finfish } \\
\text { farms }\end{array}$ \\
\hline & $\begin{array}{l}\text { 13- Ecological Footprint of } \\
\text { European countries }\end{array}$ & $\begin{array}{l}\text { 13) Ecological Footprint of European } \\
\text { countries }\end{array}$ \\
\hline $\begin{array}{l}\text { Status of access and } \\
\text { benefit sharing }\end{array}$ & $\begin{array}{l}14-\text { Percentage of European } \\
\text { patent applications ror } \\
\text { interventions based on genetic } \\
\text { resources }\end{array}$ & \begin{tabular}{|lll} 
14) Patent applications based on \\
genetic resources
\end{tabular} \\
\hline $\begin{array}{l}\text { Status of resource } \\
\text { transfers and use }\end{array}$ & 15- Funding for biodiversity & 15) Financing biodiversity management \\
\hline Public opinion & $\begin{array}{l}16-\text { Public awareness and } \\
\text { participation }\end{array}$ & 16) Public awareness \\
\hline
\end{tabular}

Source: European Environment Agency, 2007. 
Table 2: Description of the Vigie-Nature schemes

\begin{tabular}{|c|c|c|c|c|c|}
\hline & $\begin{array}{l}\text { Main } \\
\text { purpose of } \\
\text { the scheme }\end{array}$ & $\begin{array}{ll}\text { Year } & \text { of } \\
\text { creation } & \end{array}$ & $\begin{array}{l}\text { Period of } \\
\text { monitoring } \\
\text { during the year }\end{array}$ & $\begin{array}{l}\text { Domain of } \\
\text { recruitment }\end{array}$ & Audience \\
\hline $\begin{array}{l}\text { STOC-EPS } \\
\text { (common bird } \\
\text { census) }\end{array}$ & $\begin{array}{l}\text { Trends in } \\
\text { abundance }\end{array}$ & 1989 & Spring & Ornithologists & Large \\
\hline $\begin{array}{l}\text { STOC- } \\
\text { Capture (bird } \\
\text { ringing) }\end{array}$ & $\begin{array}{l}\text { Trends in } \\
\text { demographic } \\
\text { parameters }\end{array}$ & 1989 & Spring & $\begin{array}{l}\text { Experienced } \\
\text { ornithologists }\end{array}$ & Medium \\
\hline $\begin{array}{l}\text { OPJ (garden } \\
\text { butterflies } \\
\text { observation) }\end{array}$ & $\begin{array}{ll}\text { Trends } & \text { in } \\
\text { responses } & \text { to } \\
\text { global } & \\
\text { changes } & \end{array}$ & 2006 & $\begin{array}{l}\text { March } \\
\text { October }\end{array}$ & General public & Very large \\
\hline $\begin{array}{l}\text { STERF } \\
\text { (common } \\
\text { butterfly } \\
\text { census) }\end{array}$ & $\begin{array}{l}\text { Trends in } \\
\text { abundance }\end{array}$ & 2006 & $\begin{array}{l}\text { (April) May to } \\
\text { August } \\
\text { (September) }\end{array}$ & Entomologists & Small \\
\hline
\end{tabular}


Table 3: Description of the volunteer system for the Vigie-Nature schemes

\begin{tabular}{|c|c|c|c|c|}
\hline & $\begin{array}{l}\text { Interaction } \\
\text { between scientists } \\
\text { and local } \\
\text { volunteers }\end{array}$ & Technical support & $\begin{array}{l}\text { Quality control } \\
\text { mechanism (for data) }\end{array}$ & $\begin{array}{l}\text { Coordination among } \\
\text { volunteers }\end{array}$ \\
\hline $\begin{array}{l}\text { STOC-EPS } \\
\text { (monitoring } \\
\text { of common } \\
\text { birds) }\end{array}$ & $\begin{array}{l}\text { No formal contract } \\
\text { Tacit agreement } \\
\text { Personal } \\
\text { relationships } \\
\text { possible }\end{array}$ & $\begin{array}{l}\text { User-friendly } \\
\text { software provided } \\
\text { by scientists for } \\
\text { converting data } \\
\text { into a common } \\
\text { electronic format } \\
\text { Website with } \\
\text { technical } \\
\text { documentation }\end{array}$ & 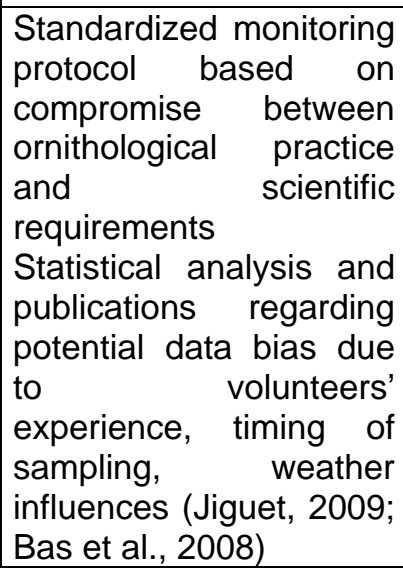 & $\begin{array}{l}\text { One national coordinator } \\
\text { and } 40 \quad \text { local } \\
\text { coordinators who } \\
\text { centralize data collected } \\
\text { by local ornithologists } \\
\text { Annual publication in } \\
\text { French ornithological } \\
\text { journal }\end{array}$ \\
\hline $\begin{array}{l}\text { STOC- } \\
\text { Capture (bird } \\
\text { ringing) }\end{array}$ & $\begin{array}{l}\text { No formal contract } \\
\text { Tacit agreement } \\
\text { for two years of } \\
\text { monitoring } \\
\text { Personal } \\
\text { relationships } \\
\text { Annual meeting for } \\
\text { discussing the } \\
\text { results } \\
\text { National training }\end{array}$ & $\begin{array}{l}\text { User-friendly } \\
\text { software provided } \\
\text { by scientists for } \\
\text { converting data } \\
\text { into a common } \\
\text { electronic format } \\
\text { Website with } \\
\text { technical } \\
\text { documentation }\end{array}$ & 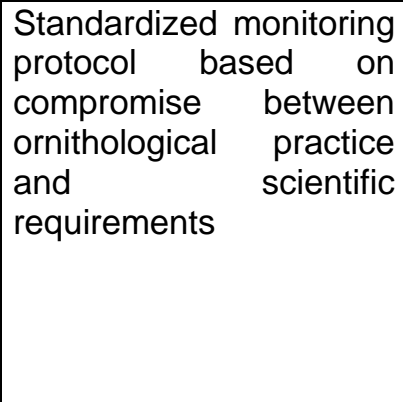 & One national coordinator \\
\hline $\begin{array}{l}\text { OPJ (garden } \\
\text { butterflies) }\end{array}$ & $\begin{array}{l}\text { No formal contract } \\
\text { No tacit agreement } \\
\text { High flexibility for } \\
\text { recruitment } \\
\text { No personal } \\
\text { relationships } \\
\text { The main goal is to } \\
\text { have as many } \\
\text { participants as } \\
\text { possible }\end{array}$ & $\begin{array}{l}\text { User-friendly for } \\
\text { website } \\
\text { uploading } \\
\text { observation data } \\
\text { Hotline } \\
\text { Website with } \\
\text { documentation on } \\
\text { protocol and } \\
\text { species } \\
\text { identification }\end{array}$ & $\begin{array}{l}\text { Standardized but very } \\
\text { simple monitoring } \\
\text { protocol aimed at } \\
\text { making data collection } \\
\text { easier } \\
\text { No standardized } \\
\text { procedure for quality } \\
\text { control, but ex-post } \\
\text { analyses show that } \\
\text { wrong data (species } \\
\text { misidentification, typing } \\
\text { mistakes) represent less } \\
\text { than } 5 \% \text { of data }\end{array}$ & $\begin{array}{l}\text { Coordination provided at } \\
\text { the national level by a } \\
\text { conservation NGO } \\
\text { through internet tools: } \\
\text { electronic newsletter, } \\
\text { forum, hotline In some } \\
\text { regions, local NGOs use } \\
\text { the OPJ for awareness- } \\
\text { raising }\end{array}$ \\
\hline $\begin{array}{l}\text { STERF } \\
\text { (butterflies) }\end{array}$ & $\begin{array}{l}\text { No formal contract } \\
\text { Tacit agreement } \\
\text { Personal } \\
\text { relationships }\end{array}$ & $\begin{array}{l}\text { User-friendly } \\
\text { software provided } \\
\text { by scientists for } \\
\text { converting data } \\
\text { into a common } \\
\text { electronic format }\end{array}$ & 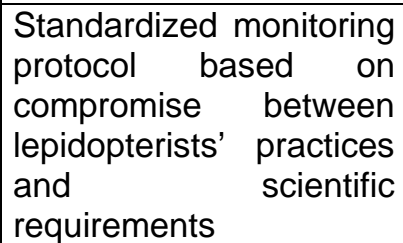 & One national coordinator \\
\hline
\end{tabular}


Table 4: Volunteer effort in the Vigie-Nature program

\begin{tabular}{|c|c|c|c|c|c|}
\hline & $\begin{array}{l}\text { A- Time per } \\
\text { visit for } \\
\text { collecting data } \\
\text { and identifying } \\
\text { species }\end{array}$ & $\begin{array}{l}\text { B- Time per visit } \\
\text { for converting } \\
\text { data into the } \\
\text { appropriate } \\
\text { electronic format }\end{array}$ & $\begin{array}{l}\text { C- Number of } \\
\text { sites * number } \\
\text { of visits per } \\
\text { year }\end{array}$ & $\begin{array}{l}\text { D- Time for } \\
\text { local } \\
\text { coordination * } \\
\text { number of } \\
\text { coordinators }\end{array}$ & $\begin{array}{l}\text { Total hours } \\
{\left[(A+B)^{\star} C\right]+D}\end{array}$ \\
\hline $\begin{array}{l}\text { STOC-EPS } \\
\text { (monitoring of } \\
\text { common } \\
\text { birds) }\end{array}$ & 2.5 hours & 1 hour & $1000 * 2$ & $5 * 40$ & $\begin{array}{l}7200 \quad(=1029 \\
\left.\text { person-days }{ }^{b}\right)\end{array}$ \\
\hline $\begin{array}{l}\text { STOC- } \\
\text { Capture (bird } \\
\text { ringing) }\end{array}$ & 10 hours & 1 hour & $160 * 4$ & 0 & $\begin{array}{l}7040 \quad(=1006 \\
\text { person-days })\end{array}$ \\
\hline $\begin{array}{l}\mathrm{OPJ}^{\mathrm{a}} \text { (garden } \\
\text { butterflies) }\end{array}$ & $\begin{array}{l}1 \text { hour (28 } \\
\text { data) }\end{array}$ & 0.1 hour & $3700 * 8.3$ & 0 & $\begin{array}{l}33781 \quad(=4826 \\
\text { person-days) }\end{array}$ \\
\hline $\begin{array}{l}\text { STERF } \\
\text { (butterflies) }\end{array}$ & 4 hours & 1 hour & $112 * 4$ & 0 & $\begin{array}{l}2240 \quad(=320 \\
\text { person-days })\end{array}$ \\
\hline
\end{tabular}

${ }^{a}$ Because there is no standardized protocol requiring a specific period of time for collecting data on garden butterflies, we have decided to estimate the time the 3700 volunteers need for collecting the 430,000 abundance data collected yearly (2006-2008) by calculating the time per month and per garden that a professional observer would be paid for. According to the coordinator of this program, collecting 14 abundance data in a garden would typically take one hour per month for a paid observer. Collecting 430,000 data represents 430,000/14 $=30,714$ hour-long sessions or $30,714 / 3700=8.3$ trips per year per site.

${ }^{\mathrm{b}}$ One person-day $=7$ hours.

Table 5: Three salary levels corresponding to three levels of ability

\begin{tabular}{|l|l|l|l|}
\hline & $\begin{array}{l}\text { Valuation A: research } \\
\text { consultancy fees }\end{array}$ & $\begin{array}{l}\text { Valuation B: public- } \\
\text { sector salaries }\end{array}$ & $\begin{array}{l}\text { Valuation } \\
\text { Guaranteed minimum } \\
\text { wage in France }\end{array}$ \\
\hline Source of information & $\begin{array}{l}\text { Average cost of an } \\
\text { expert study (figures } \\
\text { supplied by one } \\
\text { public organization, } \\
\text { one private firm, and } \\
\text { one naturalist NGO) }\end{array}$ & $\begin{array}{l}\text { Average wage for one } \\
\text { hour of work (salary } \\
\text { scale of one } \\
\text { university, one public } \\
\text { organization, and one } \\
\text { public firm) }\end{array}$ & $\begin{array}{l}\text { National guaranteed } \\
\text { minimum wage (Institut } \\
\text { National de la Statistique } \\
\text { et des Etudes } \\
\text { Economiques / National } \\
\text { Institute of Statistics } \\
\text { and } \\
\text { Studies) Economic }\end{array}$ \\
\hline $\begin{array}{l}\text { No specific skills } \\
\text { required (low } \\
\text { expertise) }\end{array}$ & $\begin{array}{l}500 \text { euros/day } \\
=71 \text { euros/hour }\end{array}$ & 13.5 euros/hour & 13.5 euros/hour \\
\hline $\begin{array}{l}\text { Long training or major } \\
\text { responsibility required } \\
\text { (medium expertise) }\end{array}$ & $\begin{array}{l}750 \text { euros/day } \\
=107 \text { euros/hour } \\
\begin{array}{l}\text { Long training and } \\
\text { major responsibility } \\
\text { required (high } \\
\text { expertise) }\end{array}\end{array}$ & 1000 euros/day \\
$=143$ euros/hour & 18 euros/hour & 13.5 euros/hour \\
\hline
\end{tabular}


Table 6: Method for calculating the costs of a biodiversity monitoring network

\begin{tabular}{|l|l|l|l|l|}
\hline & $\begin{array}{l}\text { Volunteer } \\
\text { profiles }\end{array}$ & $\begin{array}{l}\text { Total } \\
\text { hours }\end{array}$ & Level of ability required & Costs $/$ hour* \\
\hline $\begin{array}{l}\text { STOC-EPS } \\
\text { (monitoring } \\
\text { of common } \\
\text { birds) }\end{array}$ & $\begin{array}{l}\text { Ornithologis } \\
\mathrm{t}\end{array}$ & 7200 & $\begin{array}{l}\text { Be able to identify 180 birds = long } \\
\text { training and minor responsibility }\end{array}$ & $\begin{array}{l}\mathrm{A}=107 \text { euros } \\
\mathrm{B}=15 \text { euros } \\
\mathrm{C}=13.5 \text { euros }\end{array}$ \\
\hline $\begin{array}{l}\text { STOC- } \\
\text { Capture } \\
\text { (bird web } \\
\text { ring) }\end{array}$ & $\begin{array}{l}\text { Ornithologis } \\
\mathrm{t} \text { specific with } \\
\text { skills }\end{array}$ & 7040 & $\begin{array}{l}\text { Have a license, have followed an official } \\
\text { national training program (long training } \\
\text { with several sessions), be able to identify } \\
\text { species and assess demographic pattern } \\
\text { (sex, age, weight, etc.) }=143 \text { euros } \\
\text { and major responsibility }\end{array}$ & $\begin{array}{l}\mathrm{A}=18 \text { euros } \\
\mathrm{C}=13.5 \text { euros }\end{array}$ \\
\hline $\begin{array}{l}\text { OPJ (garden } \\
\text { butterflies) }\end{array}$ & $\begin{array}{l}\text { Volunteer } \\
\text { Be able to identify 28 butterflies = little } \\
\text { training and minor responsibility }\end{array}$ & $\begin{array}{l}\mathrm{A}=71 \text { euros } \\
\mathrm{B}=13.5 \text { euros } \\
\mathrm{C}=13.5 \text { euros }\end{array}$ \\
\hline $\begin{array}{l}\text { STERF } \\
\text { (butterflies) }\end{array}$ & $\begin{array}{l}\text { Entomologis } \\
\mathrm{t}\end{array}$ & 2240 & $\begin{array}{l}\text { Be able to identify 260 butterfly species } \\
=\text { long training and minor responsibility }\end{array}$ & $\begin{array}{l}\mathrm{A}=107 \text { euros } \\
\mathrm{B}=15 \text { euros } \\
\mathrm{C}=13.5 \text { euros }\end{array}$ \\
\hline
\end{tabular}

${ }^{\star} \mathrm{A}=$ environmental research consultancy fee; $\mathrm{B}=$ salary in public organization; $\mathrm{C}=$ guaranteed minimum wage 
Table 7: Level of effort of biodiversity monitoring for Vigie-Nature schemes, European schemes, and French schemes

\begin{tabular}{|c|c|c|c|c|c|c|c|}
\hline & \multicolumn{2}{|c|}{$\begin{array}{l}\text { Vigie-Nature monitoring } \\
\text { schemes for birds }\end{array}$} & \multicolumn{2}{|c|}{$\begin{array}{l}\text { Vigie-Nature monitoring schemes } \\
\text { for butterflies }\end{array}$} & \multicolumn{2}{|c|}{ European monitoring schemes } & \multirow{2}{*}{\begin{tabular}{|l|l|}
$\begin{array}{l}\text { French } \\
\text { monitoring } \\
\text { schemes }\end{array}$ \\
All taxonomic \\
groups (median of \\
$93 \quad$ monitoring \\
schemes)
\end{tabular}} \\
\hline & $\begin{array}{l}\text { STOC-EPS } \\
\text { (monitoring of } \\
\text { common birds) }\end{array}$ & $\begin{array}{l}\text { STOC-Capture } \\
\text { (bird ringing) }\end{array}$ & $\begin{array}{l}\text { OPJ (garden } \\
\text { butterflies) }\end{array}$ & \begin{tabular}{|l} 
STERF \\
(butterflies)
\end{tabular} & $\begin{array}{l}\text { Birds (median of } 149 \\
\text { monitoring } \\
\text { schemes) }\end{array}$ & $\begin{array}{|lr|}\text { Butterflies } & \text { (median of } \\
37 & \text { monitoring } \\
\text { schemes) } & \end{array}$ & \\
\hline $\begin{array}{l}\text { Number of } \\
\text { person-days }\end{array}$ & 1029 & 1006 & 4826 & 320 & 150 & 122 & 68 \\
\hline $\begin{array}{l}\text { Number of } \\
\text { visits per year }\end{array}$ & 2 & 4 & 8 & 4 & 2 & 3 & 3 \\
\hline Number of sites & 1000 & 160 & 3700 & 112 & 23 & 50 & 22 \\
\hline $\begin{array}{l}\text { Proportion of } \\
\text { volunteers }\end{array}$ & $75 \%^{a}$ & $75 \%^{a}$ & $75 \%^{a}$ & $75 \%^{a}$ & $71.4 \%$ & $50 \%$ & $66.7 \%$ \\
\hline $\begin{array}{l}\text { Number of } \\
\text { person-days per } \\
\text { site and visit }\end{array}$ & 0.51 & 1.57 & 0.16 & 0.71 & 3.26 & 0.81 & 0.11 \\
\hline
\end{tabular}

${ }^{a}$ Average for all the Vigie-Nature schemes

Source: Schmeller et al., 2009 and Vigie-Nature Program 
Table 8: Alternative value of biodiversity monitoring networks

\begin{tabular}{|l|l|l|l|l|}
\hline & $\begin{array}{l}\text { Valuation A: } \\
\text { research } \\
\text { consultancy } \\
\text { costs (euros) }\end{array}$ & $\begin{array}{l}\text { Valuation B: B: } \\
\text { public salaries } \\
\text { (euros) }\end{array}$ & $\begin{array}{l}\text { Valuation } \\
\text { Guaranteed } \\
\text { minimum wage } \\
\text { (euros) }\end{array}$ & $\begin{array}{l}\text { Full-time } \\
\text { employment } \\
\text { (1600 hours/year) }\end{array}$ \\
\hline $\begin{array}{l}\text { STOC-EPS } \\
\text { (monitoring of } \\
\text { common birds) }\end{array}$ & 770,400 & 108,000 & 97,200 & $\begin{array}{l}\text { Between 4 and 5 } \\
\text { full-time } \\
\text { employees }\end{array}$ \\
\hline $\begin{array}{l}\text { STOC-Capture } \\
\text { (bird web ring) }\end{array}$ & $1,006,720$ & 126,720 & 95,040 & $\begin{array}{l}\text { Between 4 and 5 } \\
\text { full-time } \\
\text { employees full-time }\end{array}$ \\
\hline $\begin{array}{l}\text { OPJ (garden } \\
\text { butterflies) }\end{array}$ & $2,398,451$ & 456,043 & 456,043 & $\begin{array}{l}\text { 21 } \\
\text { employees }\end{array}$ \\
\hline $\begin{array}{l}\text { STERF and 2 } \\
\text { (butterflies) }\end{array}$ & 239,680 & 33,600 & $\begin{array}{l}\text { Between 1 and-time } \\
\text { employees }\end{array}$ \\
\hline $\begin{array}{l}\text { Total of public } \\
\text { money and full- } \\
\text { time positions } \\
\text { saved by the } \\
\text { French state and } \\
\text { society }\end{array}$ & $4,415,251$ & 724,363 & $\begin{array}{l}\text { Around 31 full- } \\
\text { time employees }\end{array}$ \\
\hline
\end{tabular}

